${ }^{4}$ Tanner JM, Whitehouse RH, Takaishi M. Standards from birth to maturity for height, weight, height velocity and weight velocity: British children, 1965. Arch Dis Child 1966;41:454-71.

5 Tanner JM. Population differences in body size, shape, and growth rate: a 1976 view. Arch Dis Child 1976;51:1-2.
Correspondence to Dr J M H Buckler, University Department of Paediatrics and Child Health, The General Infirmary at Leeds, Belmont Grove, Leeds LS2 9NS.

Received 2 September 1985

\title{
Wiedemann-Beckwith syndrome in one of monozygotic twins
}

\author{
B BOSE, R A WILKIE, M MADLOM, J S FORSYTH, AND M J W FAED \\ Departments of Child Health and Cytogenetics, Ninewells Hospital and Medical School, Dundee
}

SUMMARY A pair of monozygotic twins discordant for Wiedemann-Beckwith syndrome is described. The probability of monozygosity is 0.995 . This observation suggests that the syndrome is unlikely to be under single gene control and genetic counselling should be based on multifactorial inheritance.

More than 20 years ago Wiedemann and Beckwith independently described a new syndrome characterised by exomphalos, macroglossia, and gigantism. ${ }^{12}$ Since then there have been reports identifying the Wiedemann-Beckwith syndrome and drawing attention to the frequency of familial cases. ${ }^{2}$ Attempts have subsequently been made to explain the aetiology of this condition in genetic terms and mechanisms such as autosomal recessive, autosomal dominant, premutation, and delayed mutation have all been postulated. ${ }^{2}$ We report the occurrence of the syndrome in one of a pair of monozygotic twins and suggest that the aetiology of this condition is therefore unlikely to be under single gene control.

\section{Case report}

A pair of monozygotic female twins were born to a 28 year old, para 1 , healthy woman at 36 weeks' gestation by spontaneous vertex delivery. The parents were unrelated, and the antenatal period was uneventful. Father and maternal grandfather suffered from diabetes mellitus. The 3 year old sibling was healthy. At birth a single monochorionic placenta was noted.

The proband, first of the twins, weighed $2430 \mathrm{~g}$ ( $>10$ th centile), the co-twin weighing $2130 \mathrm{~g}(<10$ th centile). The most striking features on examination of the proband were macroglossia, moderate sized exomphalos, and widely spaced nipples. No indentation of the ear lobules was noted. Early hypoglycaemia was managed with dextrose infusion, and the exomphalos was corrected within the first 24 hours of life. The second twin was of normal appearance but was small for gestational age. There were no neonatal problems. Examination of the parents did not reveal any ear creases, posterior pits, or divarication of rectus muscles, and they were not of large birthweight.

After initial catch up growth the second twin's growth variables at the age of 18 months continued along the 10th centile, and developmental assessment at that age was within normal limits. The proband had feeding difficulties related to her macroglossia, and partial glossectomy was eventually performed at the age of 17 months. Despite these problems her growth has continued along the 50 th centile for height, weight, and occipitofrontal head circumference. At the age of 18 months her development was delayed by six months. No abdominal mass was detected at any time.

Investigations to determine zygosity showed both twins to be of blood groups A, rr. They were identical when typed for Kell, $\mathrm{Fy}^{\mathrm{a}}, \mathrm{Jk}^{\mathrm{a}}, \mathrm{P} 1$, and MNS. In the HLA system both were A 3, 30, B7, 13, and $\mathrm{CW} 7$. The parents were also typed and the final probability of monozygosity was $\mathbf{0 . 9 9 5}$. Chromosomal preparations were made from cells cultured from peripheral blood of both twins and stained to reveal both $\mathrm{C}$ and $\mathrm{G}$ bands. No differences were observed in $\mathrm{C}$ band polymorphisms, thus supporting monozygosity, and no abnormality was detectable on any chromosome of either child. Chromosome 11 was particularly closely examined on prometaphase cells.

\section{Discussion}

The occurrence of Wiedemann-Beckwith syndrome in one of a pair of monozygotic twins is described with the affected twin showing the classical features of the syndrome-namely, exomphalos, macroglossia, and hypoglycaemia. The one previously pub- 
lished report of this syndrome occurring in one of a pair of monozygotic twins described a 7 week old girl presenting with hypoglycaemia, macroglossia, and hemihypertrophy but without exomphalos. ${ }^{3}$ Our case gives further support to the argument that a simple genetic mechanism is unlikely to be the sole cause of this condition.

The occurrence of familial cases does suggest that there is some genetic contribution, and the manifestation of this syndrome may depend on other environmental factors. We and several other authors ${ }^{2}$ have noted the occurrence of diabetes mellitus in many of these families, but in what way abnormal carbohydrate metabolism may predispose to the condition is unknown. The genes for insulin and an insulin like growth factor (IGF II) have been shown to be located on chromosome 11, and apparent partial duplication of the short arm of chromosome 11 has been found in association with Wiedemann-Beckwith syndrome. ${ }^{45}$ This suggests that a gene or genes, important in the expression of both diabetes and the syndrome, may be located on the short arm of chromosome 11.

The discordance has also to be explained. Although no visible chromosomal difference between the twins can be detected, the possibility of a submicroscopic post-zygotic mutation cannot be discounted. Abnormality occurring in one of monozygotic twins has been reported in other conditions, and it has been suggested that this is due to anomalies in blood supply to the two infants. ${ }^{6}$ In our case and that of Berry et al ${ }^{3}$ the normal infant was much smaller than the affected one, which may be related to the underlying syndrome or may reflect a discrepancy in the blood supply to the twins in utero. In the absence of more certain information on the aetiology of this condition genetic counselling in these families should be based on multifactorial inheritance.

We thank Dr E Brookes, director, and Mr A O'Sullivan, chief medical laboratory scientific officer, of the East of Scotland Blood Transfusion Service for their help and Ms M Hughes for typing the manuscript.

\section{References}

1 Wiedemann HR. Complexe malformatif familial avec hernie ombilicale et macroglossie. Un 'syndrome nouveau'? J Genet Hum 1964;13:223-5.

${ }^{2}$ Fillipi G, McKusick VA. The Beckwith-Wiedemann syndrome. Medicine 1970;49:279-98.

3 Berry CA, Belton EM, Chantler C. Monozygotic twins discordant for Wiedemann-Beckwith syndrome and the implications $ᄋ$ for genetic counselling. J Med Genet 1980;17:136-8.

${ }^{4}$ Tricoli JV, Rall LB, Scott J, Bell GI, Shows TB. Localization of insulin like growth factor genes to human chromosome 11 and 12. Nature 1984;310:784-6.

5 Waziri M, Patil SR, Hanson JW, Bartley JA. Abnormality of chromosome 11 in patients with features of BeckwithWeidemann syndrome. J Pediatr 1983;102:873-6.

${ }^{6}$ Albert AGL, Schinzel MD, David W, Smith MD, Miller JF Monozygotic twinning and structural defects. J Pediou 1979;95:921-30.

Correspondence to Dr B Bose, Paediatric Registrar, Departme of Child Health, Ninewells Hospital and Medical School, Dundee DD1 9SY.

Received 5 August 1985 